\title{
A unified perspective on the adoption of online teaching in higher education during the COVID-19 pandemic
}

\begin{tabular}{|r|l|}
\hline Journal: & Information Discovery and Delivery \\
\hline Manuscript ID & IDD-09-2020-0114.R1 \\
\hline Manuscript Type: & Original Article \\
\hline Keywords: & $\begin{array}{l}\text { Developing Countries, End users, Higher education, Information Science, } \\
\text { User studies, Technology }\end{array}$ \\
\hline \multicolumn{2}{|l}{}
\end{tabular}

\section{SCHOLARONE \\ Manuscripts}


A unified perspective on the adoption of online teaching in higher education during the COVID19 pandemic

\section{Abstract \\ Purpose}

The research develops a theoretical model that highlights the determinants of the adoption of online teaching at the time of the outbreak of COVID-19. This study adopted a time series analysis (TSA) to understand the factors leading to the adoption of online teaching.

\section{Methodology}

Empirical data were gathered from 222 university faculty members by employing an online survey. In the first phase, data were collected from those faculty members who had no experience of conducting online classes but were supposed to adopt online teaching as a result of the COVID-19 pandemic and subsequent lockdown. After two weeks, a slightly modified questionnaire was forwarded to the same group of faculty members, who were conducting online classes to know their perception regarding the adoption and conduct of online teaching.

\section{Findings}

Both the proposed conceptual frameworks were investigated empirically through confirmatory factor analysis (CFA) and structural equation modeling (SEM). Significant differences were found in the perceptions of faculty members regarding before and after conducting classes through online teaching.

\section{Originality}

This study contributes to the literature by presenting and validating a theory-driven framework that accentuates the factors influencing online teaching during the outbreak of a pandemic. This research further extends UTAUT2 by introducing and validating three new constructs namely: facilitative leadership, regulatory support, and project team capability. Based on the findings, practical insights are provided to Universities to facilitate adoption, acceptance, and use of online teaching during a healthcare emergency leading to campus lockdowns or the imposition of restrictions on the physical movement of people.

Keywords-UTAUT2; online teaching; behavioral intention; actual use 


\section{Introduction}

The COVID-19 pandemic has taken the shape of an epic crisis. The entire world has been severely impacted by the disease, with several thousand people already dead, and the world economy taking a tremendous beating. This has led to unemployment, social unrest, and fueled uncertainty. In the absence of a vaccine, the only choices left for preventing further infections are social distancing and quarantine, which have been enforced by governments around the world through a mandatory lockdown in their respective countries (Mackenzie, 2020; Hamzelou, 2020; Mitjà et al., 2020; Ghosh et al., 2020). Lockdowns come with their downsides as the population has to cope with this sudden loss of freedom and restriction of movement. In India, for instance, there was a total nationwide lockdown announced in March 2020, which also included all educational institutions. For higher education institutions, mid-March is the middle of an academic semester, and as a result, institutions feared the loss of academic contact hours. However, the only way to cope with the situation was to shift from physical to virtual classrooms and promote online teaching and learning. Furthermore, despite the widespread availability of online learning technologies, their use is inefficient and sparse especially in higher education as a result of which senior management in higher education institutions (HEIs) are unable to measure the effectiveness of the use of such technologies or the inefficiencies in the system due to the lack of use of such technologies (Liu et al., 2020).

The Ministry of Human Resources Development (MHRD), which through its various agencies (such as the University Grants Commission-UGC) regulates higher education in India, rolled out several initiatives to promote online education but many HEIs were first movers and voluntarily initiated the process much in advance. Online teaching as a response to pandemics and COVID-19, in particular, started in China through their "school's out, class's in" response as an initiative to mitigate the academic loss due to the disease (Zhou et al., 2020). "School's out, the class's in", "suspending classes without stopping learning", specifically refers to China's education and teaching activities during the postponement period during the COVID19 pandemic prevention and control period (Leung et al., 2020). Other countries across the world have also adopted online learning and virtual classrooms to promote learning. In Portugal, for instance, the government has created a website (https://apoioescolas.dge.mec.pt/) to provide various free online teaching tools to teachers. Similarly, in response to COVID-19, the world's largest MOOCs platforms Coursera and edX are offering a variety of free courses, with edX offering several free courses from Harvard and The Massachusetts Institute of Technology (MIT). 
This study is an attempt to assess the adoption of online teaching in light of the COVID-19 pandemic induced lockdown. The study provides useful information for university authorities to implement hassle-free online teaching in an environment of lockdown. This study is unprecedented from many perspectives: (a) It studies the adoption of technology in higher education during an ongoing pandemic situation, which is still unfolding. This is a new context and several studies have proven earlier that the context in a study is critical while framing strategies for technological adoption especially the process of technology re-design, and adaptation by individuals and groups (Liu et al.,2020; Heilesen and Josephsen, 2008; West et al., 2006); (b) According to Liu et al., (2020), technology adoption by higher education teaching staff remains disparate and inconclusive. There was an immediate transition to shift all the existing courses in an online mode in response to the pandemic (Sangeeta and Tandon, 2020). As a complete online course requires adequate usage of multimedia tools like audio and video contents and extensive support from the technical support teams. The majority of faculty members faced the challenges like early preparation, lack of online teaching experience as well as unable to teach technical courses in-depth.

Further, the readiness of the students to attend technical online classes was also highlighted as the main concern of the university faculty members. Most of the students were unable to participate initially. The nature of participation and engaging students online was another challenge noticed by university faculty members. While teaching online, the role of online instructors transforms from knowledge transmission agents to professional guiding students (Juan et al., 2011). This role of a facilitator is more challenging when the instructor is new to online settings. This challenge of "disconnect between the way teachers were taught to teach" (p. 4) has also been highlighted in the previous study of Anderson et al., (2011).

Furthermore, adoption by academics is seen as binary when in reality, it should be seen as a qualitative process based on diffusion (Porter et al., 2016; Humbert, 2007). Keeping this in consideration, this study has followed a time series analysis (TSA)in which academics adoption intent was first measured in the early stages of the university lockdown, followed by the second round of survey after two weeks, when they had adopted online teaching. The study will contribute meticulously to the literature and provide numerous implications for the Universities. This research will help the Universities to frame guidelines for the adoption of online teaching by the academicians. This research evaluates the adoption and usage of online teaching from the teachers' perspective, a gap that this research tries to fill. This research further extends UTAUT2 by introducing and validating three new constructs namely: 
facilitative leadership, regulatory support, and project team capability. Based on the findings, practical insights are provided to Universities to facilitate adoption, acceptance, and use of online teaching during a healthcare emergency leading to campus lockdowns or the imposition of restrictions on the physical movement of people.

The rest of this paper is organized as follows: Section 2 reports the theoretical background and hypotheses formulation. The research methodology, measurement items to carry out the survey, sampling, and data collection procedures are discussed in Section 3. Section 4 includes the statistical analysis and hypotheses testing followed by Section 5, and Section 6 discussing the empirical findings in detail and excerpts implications, limitations, directions for future research, and conclusions.

\section{Theoretical background and hypotheses development}

\subsection{Frameworks of Technology Adoption}

Technology adoption encompasses how people adopt technology for use (Louho et al., 2006). In this context, different models for the introduction and adoption of information technology innovations have been elucidated by previous researchers, such as Social Cognitive Theory (SCT) (Bandura, 1986), the Technology Acceptance Model (TAM) (Davis, 1989), the Theory of Planned Behavior (Ajzen, 1991), extended TAM (Venkatesh \& Davis, 2000), the model combining TAM and the Theory of Planned Behavior (Taylor \& Todd, 1995), and the Model of PC Utilization (Thompson et al., 1991) and Unified theory of acceptance and use of technology (UTAUT and UTAUT2) (Venkatesh et al., 2003; Venkatesh et al., 2012).

Among these, UTAUT2(Unified theory of acceptance and use of technology) by Venkatesh et al., (2012) has been applied widely in various domains to understand users' behavior concerning different technologies. But the model is yet to be validated within the online teaching platform for various reasons (Tseng et al., 2019). As UTAUT2 considers the perspective of voluntary users (i.e., consumers), it matches well with online teaching. UTAUT2 is compatible with online teaching practices as faculty members include interactive simulations and animations in their teaching session which is not only entertaining and exciting (LaaserandToloza, 2017), but also helps to enhance perceived value as teachers can disseminate their knowledge widely (Li et al., 2016) while confined to their homes during a pandemic or any healthcare emergency. Therefore, this research considers UTAUT2 as a theoretical underpinning to investigate factors leading to the adoption of online teaching at the 
time of the pandemic outbreak.UTAUT2 was validated for mobile internet adoption and Venkatesh et al. (2012) invited academicians and researchers to further validate the framework using miscellaneous technologies and in diverse cultures. UTAUT2 has been contemplated as a significant model in IS adoption and proved superior to competing models (Venkatesh et al., 2012; Hong et al.,2011; Tandon et al., 2018; Dwivedi et al., 2020). UTAUT2 has been widely tested by researchers on different technologies like online shopping (Tandon et al., 2020), healthcare (Ahlan and Ahmad, 2015; Alamet al., 2020), online booking of hotels(Chang et al., 2019), online gaming (Ramirez-Correa et al., 2019), and e-government services (Al-Shafi et al., 2009). There is sparse literature available on the validation of UTAUT 2 in educational settings, especially in developing countries. Only a few studies have validated UTAUT2 in educational settings such as the adoption of the MOOC by teachers (Tseng et al., 2019), the effectiveness of online videos vs in-person training (Aria and Archer, 2018) adoption of multimedia enhanced content (El-Masri and Tarhini, 2017), acceptance of technology and teachers' activities in virtual classrooms (Radovan and Kristl, 2017). However, due to inconsistency in the findings of these studies, further research is required to validate UTAUT2 as a theoretical framework in educational settings.

As the outbreak of COVID-19 was unexpected, the direct communication and human touch between the students and the instructors were lost. Both university teachers as well as the students faced technical glitches initially leading to slow-down of learning. The time and flexibility concerns lead to a non-serious attitude among the students. A few students were uncomfortable to comprehend the technical and numerical subjects. Lack of empowerment was also another issue faced by the university teachers. Faculty members conducting online classes need to design and prepare the course content within a fortnight thereby creating another challenge for themselves. There were an urgent need and support from the technical team. Academicians need to converse with students by integrating multimedia to improve upon the learning experience which again requires adequate support from the project team. The comfort level of faculty members' with technology plays a significant role in their willingness to teach online. Therefore, variables like regulators' support, project team capability, and facilitating leadership have been identified as vital factors influencing the adoption of online teaching in India. To understand the significance of these variables in the adoption of online teaching, researchers have adopted regulators' support, facilitating leadership, and project team capability as three add-on constructs that affect the adoption of online teaching during pandemic outbreaks. 


\subsection{Hypotheses development}

This research study develops hypotheses based on UTAUT2 and validates performance expectancy, effort expectancy, facilitating conditions, social influence, price value, and hedonic motivation.

Performance expectancy (PE) is defined as "the degree to which an individual believes that using the system will help him or her to attain gains in job performance" (Venkatesh et al. 2003, p. 447). Previous research studies on technology adoption (Davis, 1989; Venkatesh et al., 2012), meta-analyses (Dwivedi et al., 2019; Williams et al., 2015), and empirical studies on online learning (Chiu and Wang, 2008; El-Masri and Tarhini, 2017; Mosunmola et al., 2018; Pynoo et al., 2011), indicated the significant and vital impact of performance expectancy on behavioral intention. Previous research studies have emphasized the significant impact of PE on the intention to adopt web-based learning tools (Tseng et al.,2019; El-Masri and Tarhini, 2017; Tarhini et al., 2016; Pynoo et al., 2011).In this study, PE has been validated to comprehend the perception of academicians about online teaching during the COVID -19 outbreak. In this study, it is projected that if university teachers consider that online teaching is beneficial and may add to their teaching experience, then they are more likely to indulge themselves with the system. Therefore, the following hypotheses have been postulated:

H1(a): Performance expectancy will positively influence university faculty members' behavioral intention to adopt online teaching during the COVID-19 pandemic outbreak.

HI(b): Performance expectancy positively influences university faculty members' behavioral intention to adopt online teaching during the COVID-19 pandemic outbreak.

Effort Expectancy (EE) is analogous to ease of use (TAM) and is defined as "the degree of ease associated with the use of the system"' (Venkatesh et al. 2003, p. 450). The literature available indicates the mixed impact of EE on BI, for example, EE had a weak impact on BI in the study of Pynoo et al., (2011) but emerged as a strong predictor in a majority of the studies (Gruzd et al., 2012; Šumak et al., 2011; El-Masri and Tarhini, 2017; Mosunmola et al., 2018). In the context of this research, EE was included to investigate whether online teaching is easy to use. Academicians will adopt the online mode of delivery only when they will find the whole system easy to use and understand so that they can conduct classes smoothly. The following hypotheses have been proposed based on the above discussion: 
H2(a): Effort expectancy will positively influence university faculty members' behavioral intention to adopt online teaching during the COVID-19 pandemic outbreak.

H2(b): Effort expectancy positively influences university faculty members' behavioral intention to adopt online teaching during the COVID-19 pandemic outbreak.

Facilitating Conditions $(F C)$ is described as, "the degree to which an individual considers that an organization and technical infrastructure exists to support the use of the system" (Venkatesh et al., 2003, p.453). It refers to the perception of the extent to which the existing organizational and technical infrastructure supports the use of technology (Wiliams et al., 2011; Banerjee and Dey 2013). In the context of this research, FC will be validated by the perception of the academicians whether they can access the essential sources and support to deliver classes online. The $\mathrm{FC}$ is a vital construct to understand the intention of humans to adopt any technology (Tandon and Kiran, 2019; El-Masri and Tarhini, 2017; Mosunmola et al., 2018). FC has emerged as the strongest predictor within the e-learning context in most of the studies (Sawang et al. 2014; El-Masri and Tarhini, 2017; Wong, 2016) but in the study of Pynoo et al., (2011), FC had a weak impact on behavioral intention. Therefore, it is important to investigate whether FC has a direct relationship with the adoption of online teaching by academicians. Following hypotheses have been proposed based on the above discussion:

H3(a): Facilitating conditions will positively influence university faculty members' behavioral intention to adopt online teaching during the COVID-19 pandemic outbreak.

H3(b): Facilitating conditions positively influence university faculty members' behavioral intention to adopt online teaching during the COVID-19 pandemic outbreak.

Social Influence (SI)represents "the degree to which an individual perceives that important others believe he or she should use the new system"' (Venkatesh et al. 2003, p. 451). Social influence considers the opinions and impact of thoughts and activities on the technology adoption of a person (Tosuntas et al., 2015). Professional colleagues, siblings, friends, and peers have a positive or negative influence on intention towards any technology (Tandon and Kiran, 2019; Alalwan et al., 2016; Teo and Noyes, 2014). The adoption of online delivery of classes is generally influenced by superiors/lecturers' pressures (Tseng et al., 2019; El-Masri and Tarhini, 2017; Tosuntas et al., 2015; Pynoo et al., 2011). Therefore, the related hypotheses based on the above discussion are: 
H4(a): Social influence will positively influence university faculty members' behavioral intention to adopt online teaching during the COVID-19 pandemic outbreak.

H4(b): Social influence positively influences university faculty members' behavioral intention to adopt online teaching during the COVID-19 pandemic outbreak.

Hedonic Motivation (HM) has been defined as "an internal form of incentive, which may include fun, enjoyment, or pleasure derived from using any technology" (Venkatesh et al., 2012, p.161). Hedonic motivation is an intrinsic motivation that signifies the degree to which enjoyment is resultant of using IT (Park et al., 2012; Mittal et al., 2020). A strong positive association was found between hedonic motivation and intention to adopt e-learning (Lewis et al., 2013; Raman and Don, 2013). It is projected in this study that academicians are intrinsically interested and feel excited while delivering online classes. Those faculty members who perceive online teaching as entertaining are more likely to adopt and deliver classes online. Subsequently, based on the above discussion, the following hypotheses are proposed:

H5(a): Hedonic motivation will positively influence university faculty members'behavioral intention to adopt online teaching during the COVID-19 pandemic outbreak.

H5(b): Hedonic motivation positively influences university faculty members' behavioral intention to adopt online teaching during the COVID-19 pandemic outbreak

Price Value $(P V)$ has been defined as, “consumers' cognitive trade-off between the perceived benefits of the applications and the monetary cost for using them" (Venkatesh et al., 2012, p.161). Price value indicates the perceived benefits of technology concerning monetary value and cost (Sweeney and Soutar, 2001). The direct associations between price value and behavioral intention have been justified by prior investigations on UTAUT (Tandon and Kiran, 2019; Tarhini et al., 2016) and online learning (Raman and Don, 2013; El-Masri and Tarhini, 2017; Tseng et al., 2019). It is expected that if teachers believe that the benefits of online teaching are greater than the monetary cost, then probably, they may adopt online teaching. Accordingly, the following hypotheses have been posited:

H6(a): Price value will positively influence university faculty members' behavioral intention to adopt online teaching during the COVID-19 pandemic outbreak.

H6(b): Price value positively influences university faculty members' behavioral intention to adopt online teaching during the COVID-19 pandemic outbreak. 
UTAUT has been investigated in the context of the adoption of learning practices, but the literature is highly inconsistent. For example, Tesng et al., (2019) validated UTAUT2 to understand the adoption of MOOC courses by teachers and found significant relationships between all the constructs of UTAUT2, except for effort expectancy. Nikou and Eonomides (2019) validated the extended TAM and found perceived ease of use, facilitating conditions as determinants of behavioral intention to use mobile-based assessments. Pynoo et al., (2011) examined UTAUT to study the digital learning environment among teachers. The findings of the study confirmed the minimal role of effort expectancy and facilitating conditions, while performance expectancy and social influence had a strong impact on the acceptance of the digital learning environment. Further, effort expectancy had a weak impact on behavioral intention in the study of Pynoo et al., (2011), but emerged as a strong predictor in the study of Gruzd et al., (2012). Similarly, the studies of Pynoo et al., (2011) and Teo and Noyes (2014) confirmed a strong influence of social influence but the studies of Gruzd et al., (2012) countered this. Furthermore, facilitating conditions emerged the strongest predictor in the studies of Tesng et al., (2019) and Nikou and Eonomides (2019), but was found weak construct in the studies of Pynoo et al., (2011), and Gruzd et al., (2012). Due to inconsistent findings, there is a need to validate UTAUT2 in educational learning.

Regulatory Support (RS) plays an important role in the adoption of practicing any technology within a country. Dutton et al., (2004) advocated that adopting any new technology by academicians is driven by various political agendas. Regulatory bodies in India (UGC, AICTE) realized the economic impact of the pandemic and facilitated e-learning (Jain and Kathpalia, 2020). The processes and protocols established by regulatory bodies assist in the adoption of any technology. During the outbreak of COVID 19, the Ministry of Human Resources Development (MHRD), came out with several initiatives to promote online education, but several HEIs voluntarily initiated the process much in advance. To understand the role of regulatory bodies following hypotheses have been posited:

H7(a): Regulators' support will positively influence university faculty members' behavioral intention to adopt online teaching during the COVID-19 pandemic outbreak.

H7(b): Regulators' support influences university faculty members' behavioral intention to adopt online teaching during the COVID-19 pandemic outbreak.

Project team capability $(P T)$ has been defined as, "the technical and interpersonal skills of the members of the project team" (Liu, 2011). In Universities, various protocols and procedures 
are established, which facilitate the adoption of any technology. In the University setup, adequate support and training from the team members assist in conducting classes without any hassles. The presence of a competent team permits them to practice their expertise and understanding to facilitate internal processes (Wolff, 2008).

H8(a): Project team capability will positively influence university faculty members' behavioral intention to adopt online teaching during the COVID-19 pandemic outbreak.

H8(b): Project team capability influences university faculty members' behavioral intention to adopt online teaching during the COVID-19 pandemic outbreak.

Facilitative Leadership (FL) includes the leadership of senior management and HODs (Heads of the Department). Support from top management plays an indispensable role in strengthening and resource allocation thereby redefining priorities (Liu, 2011; Blevins and Brill, 2017). Swan (2009) highlighted that facilitative leadership leads to wide participation in such initiatives at the departmental level. Nichols (2008) emphasized that encouragement from senior management facilitates the adoption of technologies leading to ease of use, which boosts the implementation of any technology. The awareness and readiness of personnel to adopt any technology depend upon the messages and signals derived from top management (Zailaniet al., 2014). Therefore, sustenance from top management and innovativeness of personnel in an organization stimulates perceived usefulness thereby simplifying technology adoption.

Based on the above discussion following hypotheses have been framed:

H9(a): Facilitating leadership will positively influence university faculty members' behavioral intention to adopt online teaching during the COVID-19 pandemic outbreak.

H9(b): Facilitating leadership influences university faculty members' behavioral intention to adopt online teaching during the COVID-19 pandemic outbreak.

Ajzen (1991) reported behavioral intentions of individuals' readiness to engage in a given behavior are an immediate antecedent of actual behavior. According to Davis (1989), intentions signal a choice that an individual has made on whether to perform a particular action or not. Besides, intentions are the outcome of a mental deliberation procedure and commitment that possibly requires a significant amount of time. Prior studies have argued that the actual behavior is determined by their intentions to perform the behavior (Park et al., 2015; Zhao et al., 2016). Further, Rauniar et al., (2014) also confirmed a positive relationship between intentions and actual use. Thus, the following hypothesis is proposed:

H10: Behavioral intention leads to the actual use of online teaching. 


\subsection{Time-series analysis (TSA) Approach}

TSA can be effectively utilized to measure the effectiveness of interventions (Kratochwill, 1978). As suggested by Marston (1988, p.15), "TSA eliminates the need for random assignment of subjects and it is possible to analyze the functional relationship between the interventions and outcomes." The study by Linden and Yarnold (2018) confirmed that TSA is considered a fairly strong quasi-experimental design, primarily through its control over regression to the mean. The study by Velicer and Fava (2003) also insisted upon the preference of TSA as it helps to comprehend the underlying naturalistic process and the pattern of change over time. There are limited research studies that have used TSA covering the Information Technology domain. Jolie and Matthew(2006) conducted a study to understand the role of Internet selfefficacy and outcome expectations in Internet usage through three-part TSA and confirmed the role of support and encouragement in the formation of self-efficacy and outcome expectations. Therefore, a TSA approach is obligatory in extracting the causes and effects of intricated relationships. Further, studying the perceptions regarding the adoption of online teaching overtime allows improved understanding as to whether their impact is temporary or whether the impact is permanent.

\section{Methodology}

\subsection{Instrument Development}

After an extensive literature revision, a survey instrument was elaborated based on established measurement scales. Most of the items were adapted from the UTAUT2 (Venkatesh et al., 2012). Two scales were developed, one to be sent to faculty members before the start of online classes and the other after during classes. The scale items were modified in the context of the online delivery of classes at the time of the pandemic. The scale of project team capability is based on the work of Zailaniet al., (2014). The scale items of "Regulators' support" and "Facilitative leadership" are new scale items, developed by researchers to comprehend the Indian scenario of online delivery of classes during the pandemic. All these scales were customized to fit in the online delivery of class context. 
The questionnaire was organized into two sections. Section-lincluded questions on demographic details of the respondents, whereas Section-2 covered scale items on major constructs in the included proposed model.

\subsection{Data collection procedures}

As the study was conducted during the lockdown, therefore mixed-method sampling technique was employed to collect data from the respondents. According to Onwuegbuzie and Collins (2007), mixed-method sampling is highly imperative where the respondents are unknown and difficult to reach. Therefore, non-probability sampling techniques such as convenience, purposive (also known as judgmental), and snowball sampling methods, have been used to contact respondents. The link of the preliminary questionnaire was referred to as research scholars and academicians of the university to check for the face validity of the questionnaire. This pilot group suggested amendments in drafting, language, and applicability of scale items. The scale was modified according to the suggestions provided by this group. The language of a few items was also modified to improve clarity.

The web-based survey was conducted due to ease in collecting the data and maintaining anonymity with respondents. This procedure helps in reducing bias (Llievaet al.,2002; Andrews et al.,2003). Another advantage of an online survey is that the researcher gets complete responses as respondents answer all the required questions, thereby reducing missing data (Andrews et al.,2003). Further, an online survey saves responses from respondents into a data file directly, thereby, reducing the burden of inputting the data and emitting transcription errors (Evans and Mathur, 2005). The economical and affordable nature of online surveys has been recognized in previous studies also (Llievaet al.,2002; Evans and Mathur, 2005). Further, since the study conducted involved TSA approach with academicians as respondents, an online survey was preferred so that they could respond as per their convenience. 
A mixed method sampling technique was employed to collect data from the respondents. According to Onwuegbuzie and Collins (2007), mixed method sampling is highly imperative where the respondents are unknown and difficult to reach. Yet, this is the case in the region of Northern India. Therefore, non-probability sampling techniques such as convenience, purposive (also known as judgmental), and snowball sampling methods, have been used to contact respondents. Two leading State Universities of North India were selected to conduct this survey. An online link covering scale items was mailed to the faculty members of these Universities. In the first round, the link was forwarded to those faculty members who had no experience of conducting online classes but were supposed to adopt online teaching as a result of the COVID-19 pandemic and subsequent lockdown. After 15 days, another link with slightly modified scale items was forwarded to the same group of faculty members, who were conducting online classes to know their perception regarding the adoption and conduct of online teaching.

To control for social desirability bias, respondents were assured of their response anonymity and motivated to respond sincerely as much as possible (Podsakoff et al., 2003; De Leeuw et al., 2008). Using the aforementioned methodology, a total of 235 filled up responses were received in return. However, a few responses in both the surveys were found incomplete or unengaged and after scrutiny, only 222 valid responses were analyzed. Kline (2010) suggested that a sample of 200 responses or larger is suitable for a complicated path model.

Since an online survey was carried out to collect data, common method bias could emerge due to a high correlation among constructs. To minimize common method bias, all constructs were subjected to a principal component factor analysis with varimax rotation. The results of the unrotated factor analysis revealed 8 factors with each construct accounting for $67 \%$ of the variation. Thus, no specific factor was noticeable (Podsakoff et al., 2003) indicating the absence of common method bias in the dataset. 
In the sample, there is a fair inclusion of respondents across gender $45.7 \%$ males and $53.8 \%$ females, and a good representation of each age group, education level, and employment status. Table 1 reports the characteristics of the respondents in more detail.

\section{Table1: Respondents' characteristics}

\begin{tabular}{lll}
\hline \multicolumn{1}{c}{ Category $\mathbf{N = 2 2 2}$} & $\mathbf{N}$ & $\mathbf{\%}$ \\
\hline Male & 102 & 45.7 \\
Female & 120 & 53.8 \\
\hline Age & $\mathbf{N}$ & $\mathbf{\%}$ \\
\hline $25-35$ & 112 & 50.2 \\
$36-45$ & 87 & 39.0 \\
Above 45 & 23 & 10.3 \\
\hline Education & $\mathbf{N}$ & $\mathbf{\%}$ \\
\hline Others & 10 & 4.5 \\
Postgraduate & 114 & 51.1 \\
Doctorate & 98 & 43.9 \\
& & \\
\hline Designation & $\mathbf{N}$ & $\mathbf{\%}$ \\
\hline Assistant Professor & 111 & 50.1 \\
Associate Professor & 72 & 32.4 \\
Professor & 38 & 17.0 \\
Others & 1 & 0.5 \\
\hline Experience of taking online classes & $\mathrm{N}$ & $\%$ \\
\hline 2 Weeks & 79 & 35.6 \\
3-6 weeks & 119 & 53.60 \\
More than 6 weeks & 24 & 10.81 \\
& & \\
\hline
\end{tabular}

\section{Data analysis and findings}

The data analysis process was conducted employing a two-step analytical approach. In the first phase, a confirmatory factor analysis (CFA) assessed the measurement model including reliability, validity, and fit on items before conducting and after conducting online classes. Second, a structural equation model (SEM) in both cases estimated the structural model to test the hypotheses.

\subsection{Study 1}

\subsubsection{Validating the Measurement Model}

Confirmatory factor analysis (CFA) was carried out to evaluate the measurement model on the data received from faculty members before the start of online classes (Table 2). Further, standardized loadings were used to assess the indicators' reliability and 0.50 was taken as a minimum threshold for the retention of measurement items (Fornell and Larcker, 1981). 
Convergent validity was assessed through item loadings, composite reliability (CR), and AVE (Average variance extracted of each construct). Table 2 shows that AVE and CR of all the constructs are more than the threshold value i.e., $\mathrm{AVE}>-0.50$ and $\mathrm{CR}>0.70$ on all occasions thereby signifying evidence of convergent validity (Bagozzi and Li, 1988). Further, the instrument also indicated satisfactory discriminant validity as an estimate of each construct is larger than the squared correlations of this construct to any other construct (Fornell and Larcker, 1981).

Table 2: Measurement Model of items before the start of online classes

\begin{tabular}{|c|c|c|c|c|c|c|}
\hline Variables & & $\begin{array}{c}\text { Std. } \\
\text { Estimate }\end{array}$ & $\begin{array}{r}\text { Std. } \\
\text { Error }\end{array}$ & $\begin{array}{l}\text { Critical } \\
\text { Ratio }\end{array}$ & $\begin{array}{l}\text { Average } \\
\text { Variance } \\
\text { Extracted }\end{array}$ & $\begin{array}{l}\text { Composite } \\
\text { Reliability }\end{array}$ \\
\hline Performance Expectancy & PEB1 & 0.755 & & & & \\
\hline Mean $=4.2173$ & PEB2 & 0.799 & 0.106 & 12.122 & 0.595 & 0.855 \\
\hline \multirow[t]{2}{*}{ Std. Dev $=0.71688$} & PEB3 & 0.801 & 0.101 & 12.162 & & \\
\hline & PEB4 & 0.729 & 0.093 & 10.946 & & \\
\hline Effort Expectancy & EEB1 & 0.82 & & & & \\
\hline Mean=3.7523 & EEB2 & 0.825 & 0.076 & 14.276 & 0.606 & 0.86 \\
\hline \multirow[t]{2}{*}{ Std. Dev $=0.84453$} & EEB3 & 0.731 & 0.078 & 12.064 & & \\
\hline & EEB4 & 0.732 & 0.07 & 12.096 & & \\
\hline Facilitating Conditions & FCB1 & 0.834 & & & & \\
\hline Mean $=4.1475$ & FCB2 & 0.788 & 0.061 & 13.774 & 0.616 & 0.865 \\
\hline \multirow[t]{2}{*}{ Std. Dev $=0.69250$} & FCB3 & 0.693 & 0.07 & 11.507 & & \\
\hline & FCB4 & 0.818 & 0.059 & 14.573 & & \\
\hline Social Influence & SIB1 & 0.843 & & & & \\
\hline Mean $=4.0270$ & SIB2 & 0.765 & 0.08 & 12.805 & 0.673 & 0.86 \\
\hline Std. Dev. $=0.84926$ & SIB3 & 0.85 & 0.063 & 14.759 & & \\
\hline Hedonic Motivation & HMB1 & 0.822 & & & & \\
\hline Mean=4.2297 & HMB2 & 0.919 & 0.062 & 17.233 & 0.774 & 0.991 \\
\hline Std. Dev $=0.74554$ & HMB3 & 0.895 & 0.058 & 16.571 & & \\
\hline Price Value & PVB1 & 0.806 & & & & \\
\hline Mean $=4.2387$ & PVB2 & 0.868 & 0.064 & 14.534 & 0.711 & 0.88 \\
\hline Std. Dev $=0.72849$ & PVB3 & 0.854 & 0.069 & 14.248 & & \\
\hline Regulators' support & GPB1 & 0.916 & & & & \\
\hline Mean $=4.3679$ & GPB2 & 0.716 & 0.069 & 11.94 & 0.608 & 0.821 \\
\hline Std. Dev $=0.63603$ & GPB3 & 0.688 & 0.061 & 11.326 & & \\
\hline Project team capability & PTB1 & 0.897 & & & & \\
\hline Mean=4.2417 & РTB2 & 0.873 & 0.057 & 17.88 & 0.755 & 0.902 \\
\hline Std. Dev $=0.67500$ & РTB3 & 0.835 & 0.059 & 16.532 & & \\
\hline Facilitating leadership & FLB1 & 0.869 & & & & \\
\hline Mean $=4.5090$ & FLB2 & 0.84 & 0.062 & 14.963 & 0.688 & 0.869 \\
\hline Std. Dev $=0.58785$ & FLB3 & 0.777 & 0.056 & 13.434 & & \\
\hline
\end{tabular}




\begin{tabular}{lllllllllll}
\hline & PEB & EEB & FCB & HMB & PVB & SIB & GPB & PTB & FLB & BIB \\
\hline PEB & $\mathbf{0 . 7 7 1}$ & & & & & & & & &
\end{tabular}

$\begin{array}{lll}\text { EEB } & .580^{* *} & 0.778\end{array}$

$\begin{array}{llll}\text { FCB } \quad .605^{* *} & .633^{* *} & 0.784\end{array}$

$\begin{array}{lllll}\text { HMB } & .658^{* *} & .746^{* *} & .752^{* *} & 0.879\end{array}$

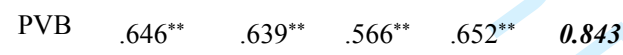

$\begin{array}{lllllll}\mathrm{SIB} & .554^{* *} & .569^{* *} & .565^{* *} & .577^{* *} & .653^{* *} & \mathbf{0 . 8 2 0}\end{array}$

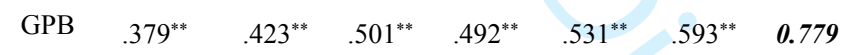

$\begin{array}{lllllllll}\text { PTB } & .515^{* *} & .508^{* *} & .575^{* *} & .480^{* *} & .466^{* *} & .495^{* *} & .430^{* *} & \mathbf{0 . 8 6 8}\end{array}$

$\begin{array}{llllllllll}\text { FLB } & .586^{* *} & .537^{* *} & .559^{* *} & .543^{* *} & .569^{* *} & .519^{* *} & .366^{* *} & .602^{* *} & \mathbf{0 . 8 2 9}\end{array}$

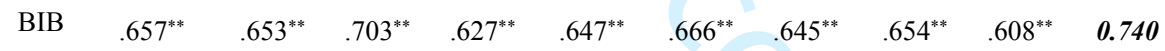

**. Correlation is significant at the 0.01 level (2-tailed).

PEB: Performance Expectancy, EEB: Effort Expectancy, FCB: Facilitating Conditions, HMB:Hedonic Motivation, PVB:Price Value, SIB: Social Influence, GPB: Government Regulators, PTB:Project Team Capability, FLB: Facilitating Leadership, BIB:Behavioral Intention

\subsubsection{Structural Model before the start of online classes}

This section examines the structural model. Table 4 also indicates the structural model reporting the theoretical associations between constructs before conducting online classes. The results claimed the following significant positive direct effects; $(i)$ from performance expectancy to behavioral intention (Std. estimate $=0.13, \mathrm{p}=0.012$ ) (ii) price value to behavioral intention (Std. estimate $=0.203, \mathrm{p}=0.000$ ) (iii) from regulators' support to behavioral intention (Std. estimate $=0.344, \mathrm{p}=0.000) ;(i v)$ from project team support to behavioral intention (Std. estimate $=0.352, \mathrm{p}=0.000) ;(v)$ facilitating leadership to behavioral intention (Std. estimate $=0.312, p=0.010$ ). Few variables had an insignificant impact on behavioral intention (vi)from effort expectancy to behavioral intention (Std. estimate $=0.131$, $\mathrm{p}=0.007)$; (vii)facilitating conditions to behavioral intention (Std. estimate $=-0.012, \mathrm{p}=0.815$ ); social influence to behavioral intention (Std. estimate $=-0.059, \mathrm{p}=0.19$ ) and (ix)hedonic motivation to behavioral intention (Std. estimate $=0.033, \mathrm{p}=0.46$ ) (Table 4). The model fit 
indices reflect a good fit to the data $\left(\chi^{2} / \mathrm{df}=4.562, \mathrm{GFI}=0.899, \mathrm{CFI}=0.905, \mathrm{TLI}=0.921\right.$, IFI $=0.902$, RMSEA $=0.079)$ as per the recommended thresholds of Byrne (1994).

Table 4: Structural Model

\begin{tabular}{llcllll}
\hline No. & Hypotheses & $\begin{array}{c}\text { Std. } \\
\text { Estimate }\end{array}$ & S.E. & C.R. & P & Results \\
\hline H1(a) & Performance expectancy $\rightarrow$ BI & 0.13 & 0.032 & 2.525 & $0.012^{* *}$ & Supported \\
H2(a) & Effort expectancy $\rightarrow$ BI & 0.061 & 0.028 & 1.153 & 0.249 & Not Supported \\
H3(a) & Facilitating conditions $\rightarrow$ BI & -0.012 & 0.034 & -0.234 & 0.815 & Not Supported \\
H4(a) & Social influence $\rightarrow$ BI & -0.059 & 0.024 & -1.311 & 0.19 & Not Supported \\
H5(a) & Hedonic motivation $\rightarrow$ BI & 0.033 & 0.027 & 0.739 & 0.46 & Not Supported \\
H6(a) & Price value $\rightarrow$ BI & 0.203 & 0.029 & 4.367 & $0.000^{* * *}$ & Supported \\
H7(a) & Regulators' support $\rightarrow$ BI & 0.344 & 0.028 & 8.683 & $0.000^{* * *}$ & Supported \\
H8(a) & Project team support $\rightarrow$ BI & 0.352 & 0.029 & 8.798 & $0.000^{* * *}$ & Supported \\
H9(a) & Facilitating leadership $\rightarrow$ BI & 0.312 & 0.024 & 9.729 & $0.000^{* * *}$ & Supported \\
\hline Note: $0.000^{* * *}$ Significant at $p<0.001$ & & & & &
\end{tabular}

Note: $0.000^{* * *}$ Significant at $p<0.001$

Insert Figure 1 here

\subsection{Study 2}

\subsubsection{Validating the measurement model}

Confirmatory factor analysis (CFA) was carried out to evaluate the measurement model on the data received from faculty members after they started conducting online classes (Table 5). Further, in this model also, standardized loadings were used to assess the indicators' reliability, and 0.50 was taken as the minimum threshold for the retention of measurement items (Fornell and Larcker, 1981). Convergent validity was assessed through item loadings, composite reliability (CR) and AVE (average variance extracted of each construct). Table 5 shows that the AVE and CR of all the constructs are more than the threshold value i.e., AVE $>-0.50$ and $\mathrm{CR}>0.70$ on all occasions thereby signifying evidence of convergent validity (Bagozzi and Li, 1988). Further, the instrument also indicated satisfactory discriminant validity as an estimate of each construct is larger than the squared correlations of this construct with any other construct (Fornell and Larcker, 1981).

Table 5: Measurement model after conducting online classes

\begin{tabular}{lccclcc}
\hline Variables & & $\begin{array}{c}\text { Std. } \\
\text { Estimate }\end{array}$ & $\begin{array}{c}\text { Std. } \\
\text { Error }\end{array}$ & $\begin{array}{l}\text { Critical } \\
\text { Ratio }\end{array}$ & $\begin{array}{l}\text { Average } \\
\text { Variance } \\
\text { Extracted }\end{array}$ & $\begin{array}{l}\text { Composite } \\
\text { Reliability }\end{array}$ \\
\hline $\begin{array}{l}\text { Performance Expectancy } \\
\text { Mean=4.4358 }\end{array}$ & PEB1 & 0.77 & & & & \\
& PEB2 & 0.81 & 0.095 & 12.106 & 0.568 & 0.855
\end{tabular}




\begin{tabular}{|c|c|c|c|c|c|c|}
\hline \multirow[t]{2}{*}{ Std. $D e v=0.68689$} & \multirow{2}{*}{$\begin{array}{l}\text { PEB3 } \\
\text { PEB4 }\end{array}$} & \multirow{2}{*}{$\begin{array}{l}0.774 \\
0.652\end{array}$} & \multirow{2}{*}{$\begin{array}{l}0.121 \\
0.089\end{array}$} & 11.539 & & \\
\hline & & & & 9.562 & & \\
\hline Effort Expectancy & EEB1 & 0.806 & & & & \\
\hline Mean $=3.9527$ & EEB2 & 0.664 & 0.067 & 10.103 & 0.576 & 0.844 \\
\hline \multirow{2}{*}{ Std. Dev $=0.77065$} & EEB3 & 0.819 & 0.07 & 12.912 & & \\
\hline & EEB4 & 0.738 & 0.069 & 11.454 & & \\
\hline Facilitating Conditions & FCB1 & 0.847 & & & & \\
\hline Mean $=4.4133$ & $\mathrm{FCB} 2$ & 0.741 & 0.061 & 12.593 & 0.655 & 0.883 \\
\hline \multirow[t]{2}{*}{ Std. Dev $=0.63377$} & FCB3 & 0.765 & 0.062 & 13.182 & & \\
\hline & FCB4 & 0.876 & 0.057 & 16.106 & & \\
\hline Social Influence & SIB1 & 0.698 & & & & \\
\hline Mean $=4.4489$ & SIB2 & 0.649 & 0.122 & 7.913 & 0.552 & 0.784 \\
\hline Std. Dev $=0.60428$ & SIB3 & 0.864 & 0.151 & 9.37 & & \\
\hline Hedonic Motivation & HMB1 & 0.775 & & & & \\
\hline Mean $=4.33634$ & HMB2 & 0.917 & 0.095 & 14.159 & 0.667 & 0.856 \\
\hline Std. Dev $=0.72317$ & HMB3 & 0.748 & 0.111 & 11.552 & & \\
\hline Price Value & PVB1 & 0.531 & & & & \\
\hline Mean $=4.2523$ & PVB2 & 0.899 & 0.283 & 8.037 & 0.606 & 0.815 \\
\hline Std. Dev $=0.70866$ & PVB3 & 0.853 & 0.276 & 8.01 & & \\
\hline Regulators' support & GPB1 & 0.916 & & & & \\
\hline Mean $=4.4294$ & GPB2 & 0.716 & 0.069 & 11.94 & 0.608 & 0.821 \\
\hline Std. Dev $=0.55268$ & GPB3 & 0.688 & 0.061 & 11.326 & & \\
\hline Project Team Capability & PTB1 & 0.787 & 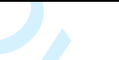 & & & \\
\hline Mean $=4.3919$ & PTB2 & 0.918 & 0.075 & 15.566 & 0.767 & 0.908 \\
\hline Std. Dev $=0.70911$ & PTB3 & 0.916 & 0.078 & 15.53 & & \\
\hline Facilitating leadership & FLB1 & 0.701 & & & & \\
\hline Mean $=4.5975$ & FLB2 & 0.89 & 0.155 & 11.957 & 0.647 & 0.845 \\
\hline Std. Dev $=0.58575$ & FLB3 & 0.811 & 0.153 & 11.116 & & \\
\hline Behavioral Intention & BIB1 & 0.804 & & & & \\
\hline Mean $=4.4797$ & BIB2 & 0.693 & 0.119 & 11.066 & 0.612 & 0.825 \\
\hline Std. Dev $=0.63793$ & BIB3 & 0.843 & 0.083 & 14.313 & & \\
\hline Actual Use & AU1 & 0.898 & & & & \\
\hline Mean=4.5511 & AU2 & 0.548 & 0.067 & 8.563 & 0.502 & 0.743 \\
\hline Std. $D e v=0.71340$ & AU3 & 0.631 & 0.078 & 10.222 & & \\
\hline
\end{tabular}

Table 6: Correlations

\begin{tabular}{|c|c|c|c|c|c|c|c|c|c|c|c|}
\hline & SI & GP & PE & EE & FC & HM & PV & SM & BI & AU & FL \\
\hline SI & 0.742 & & & & & & & & & & \\
\hline GP & $.552^{* *}$ & 0.779 & & & & & & & & & \\
\hline
\end{tabular}




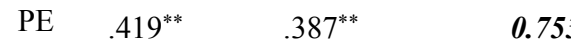

$\begin{array}{lllll}\text { EE } & .355^{* *} & .308^{* *} & .522^{* *} & 0.758\end{array}$

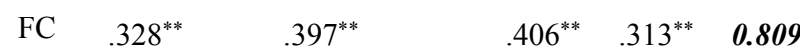

HM $306^{* *} \quad 373^{* *} \quad 545^{* *} \quad 478^{* *} \quad 419^{* *}$

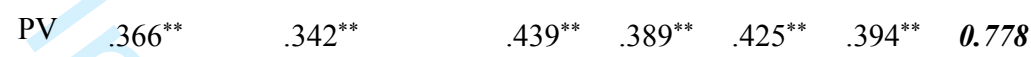

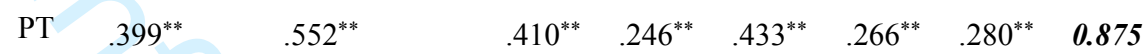

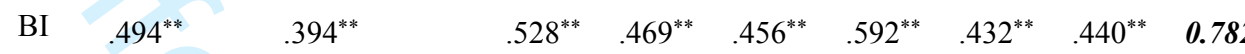

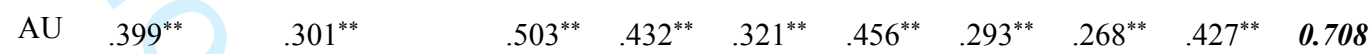

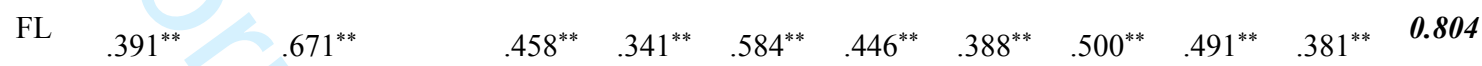

**. Correlation is significant at the 0.01 level (2-tailed).

PE: Performance Expectancy, EE: Effort Expectancy, FC:Facilitating Conditions, HM:Hedonic Motivation, PV:Price Value, SI: Social Influence, GP: Government Regulators, PT:Project Team Capability, FL: Facilitating Leadership, BI:Behavioral Intention, AU: Actual use

\subsubsection{Structural Model while conducting online classes}

The results claimed the following significant positive direct effects; $(i)$ from performance expectancy to behavioral intention (Std. estimate $=0.122, \mathrm{p}=0.020$ ) (ii) from effort expectancy to behavioral intention (Std. estimate $=0.131, \mathrm{p}=0.007$ ); (iii) from hedonic motivation to behavioral intention (Std. estimate $=0.294, \mathrm{p}=0.00$ ); (iv) from social influence to behavioral intention (Std. estimate $=0.224, \mathrm{p}=0.000) ;(v)$ facilitating leadership to behavioral intention (Std. estimate $=0.13, \mathrm{p}=0.010) ;(v i)$ Project team support to behavioral intention (Std. estimate $=0.179, \mathrm{p}=0.007)$; and viii) behavioral intention to actual use of online teaching (Std. estimate $0.786, p=0.000$ ) (Table 7). Few variables had an insignificant impact on behavioral intention such as Facilitating conditions (Std. estimate $=0.039, \mathrm{p}=0.44$, Regulators' support (Std. estimate $=-0.161, \mathrm{p}=0.058)$ and Price value $($ Std. estimate $=0.039, \mathrm{p}=0.38)$. The model fit indices reflect a good fit to the data $\left(\chi^{2} / \mathrm{df}=4.814, \mathrm{GFI}=0.902, \mathrm{CFI}=0.915, \mathrm{TLI}=0.907, \mathrm{IFI}\right.$ $=0.899$, RMSEA $=0.079)$ as per recommended thresholds of Byrne (1994). Thus, it can be concluded that the model fit summary indicates that the hypothesized structural model achieved an acceptable model fit. The study findings build an understanding of the factors leading to the adoption of virtual teaching by University professors at the time of the pandemic. 
Table 7: Structural model after conducting classes

\begin{tabular}{llcllll}
\hline No. & Hypotheses & $\begin{array}{c}\text { Std. } \\
\text { Estimate }\end{array}$ & S.E. & C.R. & P & Results \\
\hline H1(b) & Performance expectancy $\rightarrow$ BI & 0.122 & 0.049 & 2.31 & $0.020^{* * *}$ & Supported \\
H2(b) & Effort expectancy $\rightarrow$ BI & 0.131 & 0.039 & 2.72 & $0.000^{* * *}$ & Supported \\
H3(b) & Facilitating conditions $\rightarrow$ BI & 0.039 & 0.051 & 0.772 & 0.44 & Not Supported \\
H4(b) & Social influence $\rightarrow$ BI & 0.224 & 0.062 & 3.782 & $0.000^{* * *}$ & Supported \\
H5(b) & Hedonic motivation $\rightarrow$ BI & 0.294 & 0.045 & 5.673 & $0.000^{* * *}$ & Supported \\
H6(b) & Price value $\rightarrow$ BI & 0.039 & 0.039 & 0.878 & 0.38 & Not Supported \\
H7(b) & Regulators' support $\rightarrow$ BI & -0.161 & 0.07 & -2.659 & 0.058 & Not Supported \\
H8(b) & Project team support $\rightarrow$ BI & 0.179 & 0.053 & 2.707 & $0.006^{* *}$ & Supported \\
H9(b) & Facilitating leadership $\rightarrow$ BI & 0.130 & 0.053 & 2.524 & $0.010^{* *}$ & Supported \\
H10 & BI $\rightarrow$ Actual use of online teaching & 0.786 & 0.109 & 8.179 & $0.000^{* * *}$ & Supported \\
\hline & Note: $0.000^{* * *}$ Significant at $p<0.001$ & & & & \\
\hline
\end{tabular}

Insert Figure 2 here

\section{Discussion, implications, and limitations of the study}

\subsection{Discussion of the results}

This research builds a two-stage theoretical model on the adoption of online teaching by faculty members of two leading state universities at the time of the pandemic outbreak. Through an indepth analysis of data collected through two rounds of surveys, the study provides significant insights into factors influencing the adoption of online teaching at the time of pandemic outbreak COVID 19. Significant differences were observed in the behavioral intention of faculty members in both studies.

Performance expectancy emerged significant factor in both the studies which is consistent with other previous studies that confirmed that an increase in performance expectancy leads to an increase in intention to adopt any new technology(Venkatesh et al., 2012; Pynoo et al., 2011). Whereas, effort expectancy, which emerged insignificant in studyl became a significant predictor of behavioral intention in study 2. This supports the previous studies by Gupta et al., (2008) and Venkatesh et al., (2012). Therefore, it is understandable that effort expectancy was regarded as a baseline to adopt online teaching, whereas performance expectancy emerged as an important driver. As most of the teachers are digitally literate, therefore, effort expectancy had a weaker effect as compare to performance expectancy.

Surprisingly, facilitating conditions in both studies had an insignificant impact on behavioral intention to adopt online teaching. This finding is inconsistent with previously reported research studies of Venkatesh et al., (2012) and Raman and Don, (2013). Similarly, hedonic motivation also depicted varied results in both the studies. In the first study, hedonic 
motivation had an insignificant impact on behavioral intention. This could be clarified by the task nature i.e., using online teaching appeared more of a utilitarian task, and less like a hedonic task initially as the faculty members had no experience of online teaching. But in the second study, the faculty members found online teaching entertaining and full of excitement as they were able to connect with diverse audiences and work on their presentations to create interest among students provided fun and excitement to them (Hew and Cheung, 2014; Laaser and Toloza, 2017).

This research failed to explore the impact of habit on both behavioral intention and usage behavior (Venkatesh et al., 2012). This was predictable since the sample included most of the new users and a few experienced users. Therefore, it is unlikely that new users to develop habits allied with the adoption of a system. Additionally, UTAUT2 posits that habit has a minor role when the users are less experienced, but the reverse is true on more experienced users (Venkatesh et al., 2012; Tseng et al., 2019). Further, as non-users and users with less experience were considered in both the models, the habit was removed from UTAUT2.

Similarly, price value, which is an essential factor influencing faculty members' behavioral intention to adopt, and use online teaching emerged significant in study 1 but had an insignificant impact on behavioral intention in study 2. In the first study, the teachers believed that the perceived benefits of online teaching exceeded perceived costs while conducting online classes. Teachers can share subject knowledge to a larger audience (Tseng et al., 2019; Voss, 2013), which gives them a sense of accomplishment and compensates for the required time and determination. But while conducting online classes for the first time, many teachers felt tired while preparing assignments and courses. This can be overcome by providing support to teachers by giving them ample time to prepare course material and use it.

Furthermore, social influence, considered as a vital determinant of behavioral intention in the adoption of any technology emerged insignificant in study 1, which contradicts the results of previous studies (Venkatesh et al., 2012; Chopdar et al., 2018; Tseng et al., 2019). But in study 2 , social influence emerged significantly with higher loadings, thereby making us deduce that how social groups apply their influence to motivate group members to implement a particular behavior through compliance mechanisms (Hsu and Lu, 2004; Raman and Don, 2013).

All three new constructs namely, Regulators' support, Project team capability, and Facilitative leadership emerged significant in study1, while in study two, regulators emerged insignificant. Policies framed by senior management help in the adoption of any novel technology and wide 
participation leading to legitimacy (Enderle et al., 2013). Unified frameworks by the senior management help to adopt these technologies (Porter et al., 2014). Project team capability emerged significant in both the studies and the finding is consistent with the work of Liu (2011). Therefore, the presence of a competent team, the interoperability of the system as well as chosen work style of a competent team leads to the adoption of any technology (Zailani et al., 2014; Liu, 2011).

\subsection{Implications of the study}

This research has significant practical implications for university administrators to promote teachers' adoption and use of online teaching during the pandemic. Among all the constructs, performance expectancy, hedonic motivation, and social influence emerged significant variables to influence behavioral intention. For performance expectancy, the main motive to adopt online teaching during the pandemic was unquestionably their usefulness. Likely, other universities in developing countries may not have adopted online teaching during the pandemic. Therefore, the university project teams and top management need to improve the perception of the teaching staff by communicating the benefits of online teaching. Similarly, the role of social influence cannot be ruled out in facilitating the teachers in universities to adopt online teaching. Those faculty members who have adopted online teaching may demonstrate a positive attitude towards online teaching, which may be linked to their performance assessment. Top management and administrators may also invite experienced faculty members to motivate and share their experiences with other faculty members. Faculty members may be provided a preliminary video to educate them about how to teach in virtual classrooms. Those faculty members who had a positive experience may be invited to train and respond to the probable questions of non-users. Since hedonic motivation also emerged significant in this study, therefore, training faculty members to make interesting presentations and enable open communication with students. These interactions among University faculty members and students make virtual classrooms a good learning experience.

\section{Limitations and future research}

Although the results are strengthened by the TSA nature of the data, this study has a few limitations. Future research studies may include a longitudinal research design by considering the extended period as it will help in extricating the causes and effects of complicated constructs. Further, analyzing the perceptions overtime improves understanding of phenomena as to whether their impact is for a shorter period or whether the impact is enduring. Since the study is conducted in North India, the results cannot be generalized to other parts of the country. 
The model may be validated and tested in other parts of the country also and a comparative study could be considered in the future. This extended UTAUT2 may be replicated in other developing countries of the world also to see the applicability of the model. Further, this research investigated the adoption of online teaching from the perspective of UTAUT2, but only the main effects proposed by Venkatesh et al., (2012) were validated, while moderators were not validated. Future research studies may also validate the moderating effects on proposed relationships. The same model could be validated to study other platforms apart from online teaching, such as online learning by students, adoption of MOOC, etc.

\section{References}

Ahlan, A. R., \& Ahmad, B. I. E. (2015). An overview of patient acceptance of health information technology in developing countries: a review and conceptual model. International Journal of Information Systems and Project Management, 3(1), 2948.

Ajzen, I. (1991). The theory of planned behavior. Organizational Behavior and Human Decision Processes, 50(2), 179-211.

Alalwan, A. A., Dwivedi, Y. K., Rana, N. P., Lal, B., \& Williams, M. D. (2015). Consumer adoption of Internet banking in Jordan: Examining the role of hedonic motivation, habit, self-efficacy and trust. Journal of Financial Services Marketing, 20(2), 145-157.

Alam, M. Z., Hu, W., Kaium, A., Hoque, R., \&Alam, M. M. D. (2020). Understanding the determinants of mHealth apps adoption in Bangladesh: A SEM-Neural network approach. Technology in Society, 101255.

Andrews, D., Nonnecke, B. \&Preece, J. (2003). Electronic survey methodology: A case study in reaching hard to involve Internet Users. International Journal of Human-Computer Interaction, 16(2), 185-210.

Aria, R., \& Archer, N. (2018). Using an educational video vs. in-person education to measure patient perceptions of an online self-management support system for chronic illness. Computers in Human Behavior, 84, 162-170.

Bagozzi, R. P. and Yi, Y. (1991). Multitrait-Multimethod Matrices in Consumer Research. Journal of Consumer Research, 17, 426-439.

Bandura, A. (1986). The explanatory and predictive scope of self-efficacy theory. Journal of Clinical and Social Psychology, 4, 359-373.

Blevins, S., \& Brill, J. (2017). Enabling systemic change: Creating an e Portfolio implementation framework through design and development research for use by higher education professionals. International Journal of Teaching and Learning in Higher Education, 29(2), 216-232. 
Byrne, B. M. (1994). Structural equation modeling with EQS and EQS/Windows: Basic concepts, applications, and programming. Sage.

Chang, Y. W., Hsu, P. Y., \& Lan, Y. C. (2019). Cooperation and competition between online travel agencies and hotels. Tourism Management, 71, 187-196.

Cheng, Xiaoqiao, Challenges of 'School's Out, But Class's On' to School Education: Practical Exploration of Chinese Schools during the COVID-19 Pandemic (March 31, 2020). Sci Insigt Edu Front 2020; 5(2):501-516..

Chiu, C. M., \& Wang, E. T. (2008). Understanding Web-based learning continuance intention: The role of subjective task value. Information \& Management, 45(3), 194-201.

Chopdar, P. K., Korfiatis, N., Sivakumar, V. J., \& Lytras, M. D. (2018). Mobile shopping apps adoption and perceived risks: A cross-country perspective utilizing the unified theory of acceptance and use of technology. Computers in Human Behavior, 86, 109-128.

Davis, F. D. (1989). Perceived usefulness, perceived ease of use and user acceptance of information technology. MIS Quarterly, 13(3), 319-339.

De Leeuw, E. D., Hox, J. J., \&Dillman, D. A. (2008). International handbook of survey methodology. Taylor \& Francis Group/Lawrence Erlbaum Associates.

Dong, Su, Practical Exploration of Using 'Cloud Classroom' to Organize Online Learning: A Case Study of Jianye District, Nanjing during the COVID-19 Pneumonia (March 31, 2020). Sci Insigt Edu Front 2020; 5(2):553-556.

Dutton, W. H., Cheong, P. H., \& Park, N. (2004). An Ecology of Constraints on eLearning in Higher Education: The Case of a Virtual Learning Environment. Prometheus, 22(2), 131149.

El-Masri, M., Tarhini, A. (2017). Factors affecting the adoption of e-learning systems in Qatar and USA: Extending the Unified Theory of Acceptance and Use of Technology 2 (UTAUT2). Education Tech Research Dev, 65, 743-763.

Enderle, P. J., Southerland, S. A., \& Grooms, J. A. (2013). Exploring the context of change: Understanding the kinetics of a studio physics implementation effort. Physical Review Special Topics-Physics Education Research, 9(1), 010114.

Evans, J. R., \& Mathur, A. (2005). The value of online surveys. Internet Research, 15(2), 195219.

Fornell, C., \&Larcker, D. F. (1981). Evaluating structural equation models with unobservable variables and measurement error. Journal of Marketing Research, 18(1), 39-50.

Ghosh A., Gupta R., Misra A. Telemedicine for diabetes care in India during COVID19 pandemic and national lockdown period: guidelines for physicians. Diabetes MetabSyndr. 2020;14(4):273-276.

Gruzd, A., Staves, K., \& Wilk, A. (2012). Connected scholars: Examining the role of social media in research practices of faculty using the UTAUT model. Computers in Human Behavior, 28(6), 2340-2350.

Gupta, B., Dasgupta, S., \& Gupta, A. (2008). Adoption of ICT in a government organization in a developing country: An empirical study. The Journal of Strategic Information Systems, 17(2), 140-154.

Hamzelo, J. (2020). World in lockdown as coronavirus cases soar. Available online: https://www.newscientist.com/article/mg24532754-200-world-in-lockdown-ascoronavirus-cases-soar/ retrieved on 13 April, 2020.

Heilesen, S. B., \&Josephsen, J. (2008). E-learning: Between augmentation and disruption?. Computers \& Education, 50(2), 525-534.

Hew, K. F., \& Cheung, W. S. (2014). Students' and instructors' use of massive open online courses (MOOCs): Motivations and challenges. Educational research review, 12, 45-58. 
Hong, W., Thong, J. Y., Chasalow, L. C., \& Dhillon, G. (2011). User acceptance of agile information systems: A model and empirical test. Journal of Management Information Systems, 28(1), 235-272.

Hsu, C. L., \& Lu, H. P. (2004). Why do people play on-line games? An extended TAM with social influences and flow experience. Information \& Management, 41(7), 853-868.

Humbert, M. (2007). Adoption of blended learning by faculty. In The challenges of educating people to lead in a challenging world (pp. 423-436). Springer, Dordrecht.

Ilieva, J., Baron, S. \& Healey, N.M. (2002). Online surveys in marketing research: pros and cons. International Journal of Marketing Research, 44(3), 361-376.

Jain, A. and Kathpalia, V. (2020). Online Higher Education: Time for De-regulation is now! Available online onhttp://www.nishithdesai.com/information/news-storage/newsdetails/article/online-higher-education-time-for-de-regulation-is-now.htmlRetrieved on 29 April 2020.

Kline, R. B. (2010). Principles and Practice of Structural Equation Modeling, Series Editor's Note by Todd D. Little.

Laaser, W., \&Toloza, E. A. (2017). The changing role of the educational video in higher distance education. The International Review of Research in Open and Distributed Learning, 18(2).

Leung, C. C., Lam, T. H., \& Cheng, K. K. (2020). Mass masking in the COVID-19 epidemic: people need guidance. The Lancet, 395(10228), 945.

Lewis, C. C., Fretwell, Ch., Ryan, J., \& Parham, J. B. (2013). Faculty use of established and emerging technologies in higher education: A unified theory of acceptance and use of technology perspective. International Journal of Higher Education, 2(2), 22-34.

Li, S., Xu, J., van der Schaar, M., \& Li, W. (2016). Trend-aware video caching through online learning. IEEE Transactions on Multimedia, 18(12), 2503-2516.

Linden, A., \& Yarnold, P. R. (2018). Using machine learning to evaluate treatment effects in multiplegroup interrupted time series analysis. Journal of Evaluation in Clinical Practice, 24(4), 740744

Liu, C. F. (2011) Key Factors Influencing the Intention of Telecare Adoption: AnInstitutional Perspective. Telemedicine and e-Health 17(4), 288-293.

Liu, Q., Geertshuis, S., \& Grainger, R. (2020). Understanding academics' adoption of learning technologies: A systematic review. Computers \& Education, 103857.

Louho, R., Kallioja, M., \&Oittinen, P. (2006). Factors affecting the use of hybrid media applications. Graphic arts in Finland, 35(3), 11-21.

Mackenzie, W. (2020). India's renewables installation could fall by a fifth due to lockdown. Available onlinehttps://economictimes.indiatimes.com/small-biz/productline/powergeneration/indias-renewables-installation-could-fall-by-a-fifth-due-to-lockdown-woodmackenzie/articleshow/75028831.cms? from=mdr retrieved on 14 April, 2020.

Marston, D. (1988). The Effectiveness of Special Education. The Journal of Special Education, 21(4), 13-26. doi:10.1177/002246698802100405

Mitjà, O., Arenas, A., Rodó, X., Tobias, A., Brew, J. Benlloch, J.M. (2020). Experts' request to the Spanish Government: move Spain towards complete lockdown. The Lancet, 395 (10231), 1193-1194.

Mittal, A., Aggarwal, A., \& Mittal, R. (2020). Predicting University Students' Adoption of Mobile News Applications: The Role of Perceived Hedonic Value and News Motivation. International Journal of E-Services and Mobile Applications (IJESMA), 12(4), 42-59.

Nichols, M. (2008). Institutional perspectives: The challenges of e-learning diffusion. British Journal of Educational Technology, 39(4), 598-609. 
Nikou, S. A., \& Economides, A. A. (2019). Factors that influence behavioral intention to use mobile-based assessment: A STEM teachers' perspective. British Journal of Educational Technology, 50(2), 587-600.

Onwuegbuzie, A. J., \& Collins, K. M. (2007). A Typology of Mixed Methods Sampling Designs in Social Science Research . The Qualitative Report, 12(2), 281-316.

Park, E. J., Kim, E. Y., Funches, V. M., \& Foxx, W. (2012). Apparel product attributes, web browsing, and e-impulse buying on shopping websites. Journal of Business Research, 65(11), 1583-1589.

Park, M. J., Choi, H., Kim, S. K., \& Rho, J. J. (2015). Trust in government's social media service and citizen's patronage behavior. Telematics and Informatics, 32(4), 629-641.

Podsakoff, P. M., MacKenzie, S. B., Lee, J. Y., \& Podsakoff, N. P. (2003). Common method biases in behavioral research: a critical review of the literature and recommended remedies. Journal of Applied Psychology, 88(5), 879.

Porter, W. W., Graham, C. R., Bodily, R. G., \& Sandberg, D. S. (2016). A qualitative analysis of institutional drivers and barriers to blended learning adoption in higher education. The internet and Higher education, 28, 17-27.

Porter, W. W., Graham, C. R., Spring, K. A., \& Welch, K. R. (2014). Blended learning in higher education: Institutional adoption and implementation. Computers \& Education, $75,185-195$.

Pynoo, B., Devolder, P., Tondeur, J., Van Braak, J., Duyck, W., \&Duyck, P. (2011). Predicting secondary school teachers' acceptance and use of a digital learning environment: A crosssectional study. Computers in Human behavior, 27(1), 568-575.

Radovan, M., \&Kristl, N. (2017). Acceptance of Technology and Its Impact on Teachers' Activities in Virtual Classroom: Integrating UTAUT and CoI into a Combined Model. Turkish Online Journal of Educational Technology-TOJET, 16(3), 11-22.

Raman, A., \& Don, Y. (2013). Preservice teachers' acceptance of learning management software: An application of the UTAUT2 model. International Education Studies, 6(7), 157-164.

Raman, A., \& Don, Y. (2013). Preservice teachers' acceptance of learning management software: An Application of the UTAUT2 Model. International Education Studies, 6(7), 157-160.

Ramírez-Correa, P., Rondán-Cataluña, F. J., Arenas-Gaitán, J., \& Martín-Velicia, F. (2019). Analysing the acceptation of online games in mobile devices: An application of UTAUT2. Journal of Retailing and Consumer Services, 50, 85-93.

Rauniar, R., Rawski, G., Yang, J., \& Johnson, B. (2014). Technology acceptance model (TAM) and social media usage: an empirical study on Facebook. Journal of Enterprise Information Management, 27(1), 6-30.

Sangeeta \&Tandon, U. (2020). Factors influencing adoption of online teaching by school teachers: A study during COVID-19 pandemic. Journal of Public Affairs, e2503.

Shafi, A. S., \&Weerakkody, V. (2009). Understanding citizens' behavioural intention in the adoption of e-government services in the state of Qatar. In ECIS (pp. 1618-1629).

Swan, G. (2009). Information systems in teacher preparation programs: What can we learn from a 5-Year longitudinal case study of an electronic portfolio database?.Journal of Educational Computing Research, 41(4), 431-451.

Sweeney, J. C., \&Soutar, G. N. (2001). Consumer perceived value: The development of a multiple item scale. Journal of retailing, 77(2), 203-220.

Tamilmani, K., Rana, N. P., \& Dwivedi, Y. K. (2020). Consumer Acceptance and Use of Information Technology: A Meta-Analytic Evaluation of UTAUT2. Information Systems Frontiers, 1-19. 
Tandon, U., \& Kiran, R. (2018). Study on drivers of online shopping and significance of cashon-delivery mode of payment on behavioural intention. International Journal of Electronic Business, 14(3), 212-237.

Tandon, U., \& Kiran, R. (2019). Factors impacting customer satisfaction: an empirical investigation into online shopping in India. Journal of Information Technology Case and Application Research, 21(1), 13-34.

Tandon, U., Mittal, A., \& Manohar, S. (2020). Examining the impact of intangible product features and e-commerce institutional mechanics on consumer trust and repurchase intention. Electronic Markets, 1-20, available as online first.

Tarhini, A., Teo, T., \&Tarhini, T. (2016). A cross-cultural validity of the E-learning acceptance measure (ElAM) in Lebanon and England: A confirmatory factor analysis. Education and Information Technologies, 21(5), 1269-1282.

Teo, T., \& Noyes, J. (2014). Explaining the intention to use technology among pre-service teachers: a multi-group analysis of the Unified Theory of Acceptance and Use of Technology. Interactive Learning Environments, 22(1), 51-66.

Thompson, R. L., Higgins, C. A., \& Howell, J. M. (1991). Personal Computing: Toward a conceptual model of utilization. MIS Quarterly, 15(1), 125-143.

Tosuntas, S. B., Karadag, B. E., \& Orhan, S. (2015). The factors affecting acceptance and use of interactive whiteboard within the scope of FATIH project: A structural equation model based on the unified theory of acceptance and use of technology. Computers \& Education, 81(2), 169-178.

Tseng, T. H., Lin, S., Wang, Y. S., \& Liu, H. X. (2019). Investigating teachers' adoption of MOOCs: the perspective of UTAUT2. Interactive Learning Environments, 1-16.

Velicer, W. F., \& Fava, J. L. (2003). Time Series Analysis. In J. Schinka\& W. F. Velicer (Eds.), Research Methods in Psychology(581-606). Volume 2, Handbook of Psychology (I. B. Weiner, Editor-in-Chief.)New York: John Wiley \& Sons(19) (PDF) Time Series Analysis.

Venkatesh, V., \& Davis, F. D. (2000). A theoretical extension of the technology acceptance models: Four longitudinal field studies. Management Science, 46(2), 186-204.

Venkatesh, V., Morris, M. G., Davis, G. B., \& Davis, F. D. (2003). User acceptance of information technology: Towards a unified view. MIS Quarterly, 27(3), 425-478.

Venkatesh, V., Thong, J. Y. L., \& Xu, X. (2012). Consumer acceptance and use of information technology: Extending the unified theory of acceptance and use of technology. MIS Quarterly, 36(1), 157-178.

Voss, B. D. (2013). Massive open online courses (MOOCs): A primer for university and college board members. Washington, DC: AGB Association of Governing Boards of Universities and Colleges.

West, W., Rosser, B. S., Monani, S., \& Gurak, L. (2006). How Learning Styles Impact Elearning: a case comparative study of undergraduate students who excelled, passed, or failed an online course in scientific/technical writing. E-Learning and Digital Media, 3(4), 534-543.

Wolff, W. I. (2008). "A chimera of sorts": Rethinking educational technology grant programs, courseware innovation, and the language of educational change. Computers \& Education, 51(3), 1184-1197.

Wong, G. K. (2016). The behavioral intentions of Hong Kong primary teachers in adopting educational technology. Educational Technology Research and Development, 64(2), 313-338.

Zailani, S., Gilani, M. S., Nikbin, D., \&Iranmanesh, M. (2014). Determinants of telemedicine acceptance in selected public hospitals in Malaysia: clinical perspective. Journal of medical systems, 38(9), 111. 
Zhao, L., Yin, J., \& Song, Y. (2016). An exploration of rumor combating behavior on social media in the context of social crises. Computers in Human Behavior, 58, 25-36.

Zhou, L., Wu, S., Zhou, M., \& Li, F. (2020). 'School's Out, But Class' On', The Largest Online Education in the World Today: Taking China's Practical Exploration During The COVID-19 Epidemic Prevention and Control As an Example. But Class' On', The Largest Online Education in the World Today: Taking China's Practical Exploration During The COVID-19 Epidemic Prevention and Control As an Example (March 15, 2020).

Appendix1: Scale items

\begin{tabular}{|c|c|c|c|c|c|c|}
\hline & \multirow{2}{*}{$\begin{array}{l}\text { Scale items and their source } \\
\text { Performance Expectancy (Venkatesh et al., 2012) }\end{array}$} & \multicolumn{5}{|c|}{ 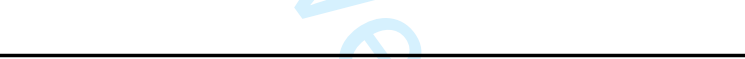 } \\
\hline & & $\begin{array}{l}\text { Strongly } \\
\text { Disagree }\end{array}$ & Disagree & Neutral & Agree & $\begin{array}{c}\text { Strongly } \\
\text { Agree }\end{array}$ \\
\hline PE1 & $\begin{array}{l}\text { I prefer to teach online during the outbreak of contagious } \\
\text { diseases because I can have access to students at distant } \\
\text { locations. }\end{array}$ & 1 & 2 & $x$ & 4 & 5 \\
\hline PE2 & $\begin{array}{l}\text { I prefer to teach online during the outbreak of contagious } \\
\text { diseases because it helps me to reach students within the } \\
\text { shortest time-frame. }\end{array}$ & 1 & 2 & 3 & 4 & 5 \\
\hline
\end{tabular}




\begin{tabular}{|c|c|c|c|c|c|c|}
\hline PE3 & $\begin{array}{l}\text { I prefer to teach online during the outbreak of contagious } \\
\text { diseases because it saves time as students can continue } \\
\text { participating in discussion sections and lectures without } \\
\text { coming to University. }\end{array}$ & 1 & 2 & 3 & 4 & 5 \\
\hline PE4 & $\begin{array}{l}\text { I prefer to teach online during the outbreak of contagious } \\
\text { diseases because It helps me to utilize the time effectively. }\end{array}$ & 1 & 2 & 3 & 4 & 5 \\
\hline \multirow[b]{2}{*}{ EE1 } & Effort Expectancy (Venkatesh et al., 2012) & & & & & \\
\hline & It is easy for me to deliver online lectures. & 1 & 2 & 3 & 4 & 5 \\
\hline EE2 & $\begin{array}{l}\text { The language used by students during the online class is } \\
\text { easy to understand. }\end{array}$ & 1 & 2 & 3 & 4 & 5 \\
\hline \multirow{2}{*}{$\begin{array}{l}\text { EE3 } \\
\text { EE4 }\end{array}$} & $\begin{array}{l}\text { I can solve the problems of students easily during an online } \\
\text { class. }\end{array}$ & 1 & 2 & 3 & 4 & 5 \\
\hline & It is easy to customize the lectures online. & 1 & 2 & 3 & 4 & 5 \\
\hline EE5 & $\begin{array}{l}\text { It is easy to participate in discussions during an online } \\
\text { class. }\end{array}$ & 1 & 2 & 3 & 4 & 5 \\
\hline \multirow[b]{2}{*}{$\mathrm{FC} 1$} & Facilitating Conditions (Venkatesh et al., 2012) & & & & & \\
\hline & $\begin{array}{l}\text { I have been provided with the resources necessary to } \\
\text { deliver online classes by my University. }\end{array}$ & 1 & 2 & 3 & 4 & 5 \\
\hline \multirow{2}{*}{$\begin{array}{l}\mathrm{FC} 2 \\
\mathrm{FC} 3\end{array}$} & I have the necessary knowledge to deliver an online lecture & 1 & 2 & 3 & 4 & 5 \\
\hline & $\begin{array}{l}\text { Delivering lectures online is compatible with other } \\
\text { technologies I use. }\end{array}$ & 1 & 2 & 3 & 4 & 5 \\
\hline FC4 & $\begin{array}{l}\text { I get help from my university when I face difficulties while } \\
\text { delivering classes online. }\end{array}$ & 1 & 2 & 3 & 4 & 5 \\
\hline \multirow[b]{2}{*}{ HM1 } & Hedonic Motivation (Venkatesh et al., 2012) & & & & & \\
\hline & Online teaching is an exciting experience for me. & 1 & 2 & 3 & 4 & 5 \\
\hline \multirow{2}{*}{ HM2 } & $\begin{array}{l}\text { Teaching students through online mode is a pleasant } \\
\text { experience for me. }\end{array}$ & 1 & 2 & 3 & 4 & 5 \\
\hline & Delivering lectures online is a fun experience for me. & 1 & 2 & 3 & 4 & 5 \\
\hline \multirow{4}{*}{$\begin{array}{l}\text { PV1 } \\
\text { PV2 } \\
\text { PV3 }\end{array}$} & Price Value (Venkatesh et al., 2012) & & & & & \\
\hline & $\begin{array}{l}\text { I think that online teaching is cost-effective for the } \\
\text { university especially during a pandemic. }\end{array}$ & 1 & 2 & 3 & 4 & 5 \\
\hline & I feel that online teaching is cost-effective for me. & 1 & 2 & 3 & 4 & 5 \\
\hline & I feel that online teaching is cost-effective for the students & 1 & 2 & 3 & 4 & 5 \\
\hline \multirow[b]{2}{*}{ SI1 } & Social Influence (Venkatesh et al., 2012) & & & & & \\
\hline & $\begin{array}{l}\text { People whose opinions I value, prefer that I should teach } \\
\text { online during a pandemic }\end{array}$ & 1 & 2 & 3 & 4 & 5 \\
\hline SI2 & $\begin{array}{l}\text { My colleagues and peers think that I should adopt an online } \\
\text { mode of teaching during a pandemic }\end{array}$ & 1 & 2 & 3 & 4 & 5 \\
\hline SI3 & $\begin{array}{l}\text { People who are important to me think that I should adopt } \\
\text { online teaching during a pandemic }\end{array}$ & 1 & 2 & 3 & 4 & 5 \\
\hline \multirow[b]{2}{*}{ GP1 } & Regulators' Support (New Scale items) & & & & & \\
\hline & $\begin{array}{l}\text { I think UGC/AICTE etc should support online teaching } \\
\text { during the outbreak of a pandemic. }\end{array}$ & 1 & 2 & 3 & 4 & 5 \\
\hline \multirow[t]{2}{*}{ GP2 } & $\begin{array}{l}\text { I think UGC/AICTE etc should provide the necessary } \\
\text { infrastructure to pursue online teaching. }\end{array}$ & 1 & 2 & 3 & 4 & 5 \\
\hline & $\begin{array}{l}\text { I think UGC/AICTE should liberalize the ICT policy } \\
\text { specifically to promote the use of online delivery of lectures } \\
\text { during a pandemic. }\end{array}$ & 1 & 2 & 3 & 4 & 5 \\
\hline \multirow{3}{*}{ PC1 } & Project team capability (Zailani and Iranmanesh, 2014) & \\
\hline & $\begin{array}{l}\text { In my university, there is a formal and qualified team to } \\
\text { facilitate online teaching during an epidemic. }\end{array}$ & 1 & 2 & 3 & 4 & 5 \\
\hline & $\begin{array}{l}\text { The project team can understand the requirements of } \\
\text { students of different departments. }\end{array}$ & 1 & 2 & 3 & 4 & 5 \\
\hline
\end{tabular}




\begin{tabular}{|c|c|c|c|c|c|c|}
\hline PC3 & $\begin{array}{l}\text { The project team has a capable information system for the } \\
\text { development of online delivery of classes. }\end{array}$ & 1 & 2 & 3 & 4 & 5 \\
\hline \multirow{3}{*}{ FL1 } & Facilitative Leadership (New Scale items) & & & & & \\
\hline & $\begin{array}{l}\text { The senior management of the University supports online } \\
\text { teaching during the pandemic }\end{array}$ & 1 & 2 & 3 & 4 & 5 \\
\hline & $\begin{array}{l}\text { Senior management has allocated resources for conducting } \\
\text { online classes during an epidemic }\end{array}$ & 1 & 2 & 3 & 4 & 5 \\
\hline FL3 & $\begin{array}{l}\text { Senior management provides a unified framework } \\
\text { operating at the departmental level for facilitating online } \\
\text { teaching during a pandemic. }\end{array}$ & 1 & 2 & 3 & 4 & 5 \\
\hline \multirow{4}{*}{$\begin{array}{l}\text { BI1 } \\
\text { BI2 } \\
\text { BI3 } \\
\end{array}$} & Behavioral Intention (Venkatesh et al., 2012) & & & & & \\
\hline & $\begin{array}{l}\text { I intend to teach online teaching during the outbreak of an } \\
\text { epidemic in the future. }\end{array}$ & 1 & 2 & 3 & 4 & 5 \\
\hline & I intend to adopt online teaching in my daily routine also. & 1 & 2 & 3 & 4 & 5 \\
\hline & $\begin{array}{l}\text { I intend to encourage my peers and colleagues to adopt } \\
\text { online teaching during the spread of contagious disease. }\end{array}$ & 1 & 2 & 3 & 4 & 5 \\
\hline & Actual Use (Venkatesh et al., 2012) & & & & & \\
\hline AU1 & $\begin{array}{l}\text { I used online teaching frequently during the spread of } \\
\text { contagious disease. }\end{array}$ & 1 & 2 & 3 & 4 & 5 \\
\hline AU2 & $\begin{array}{l}\text { I used online teaching to share my content and assignments } \\
\text { with students. }\end{array}$ & 1 & 2 & 3 & 4 & 5 \\
\hline AU3 & I am used to online teaching now. & 1 & 2 & 3 & 4 & 5 \\
\hline
\end{tabular}




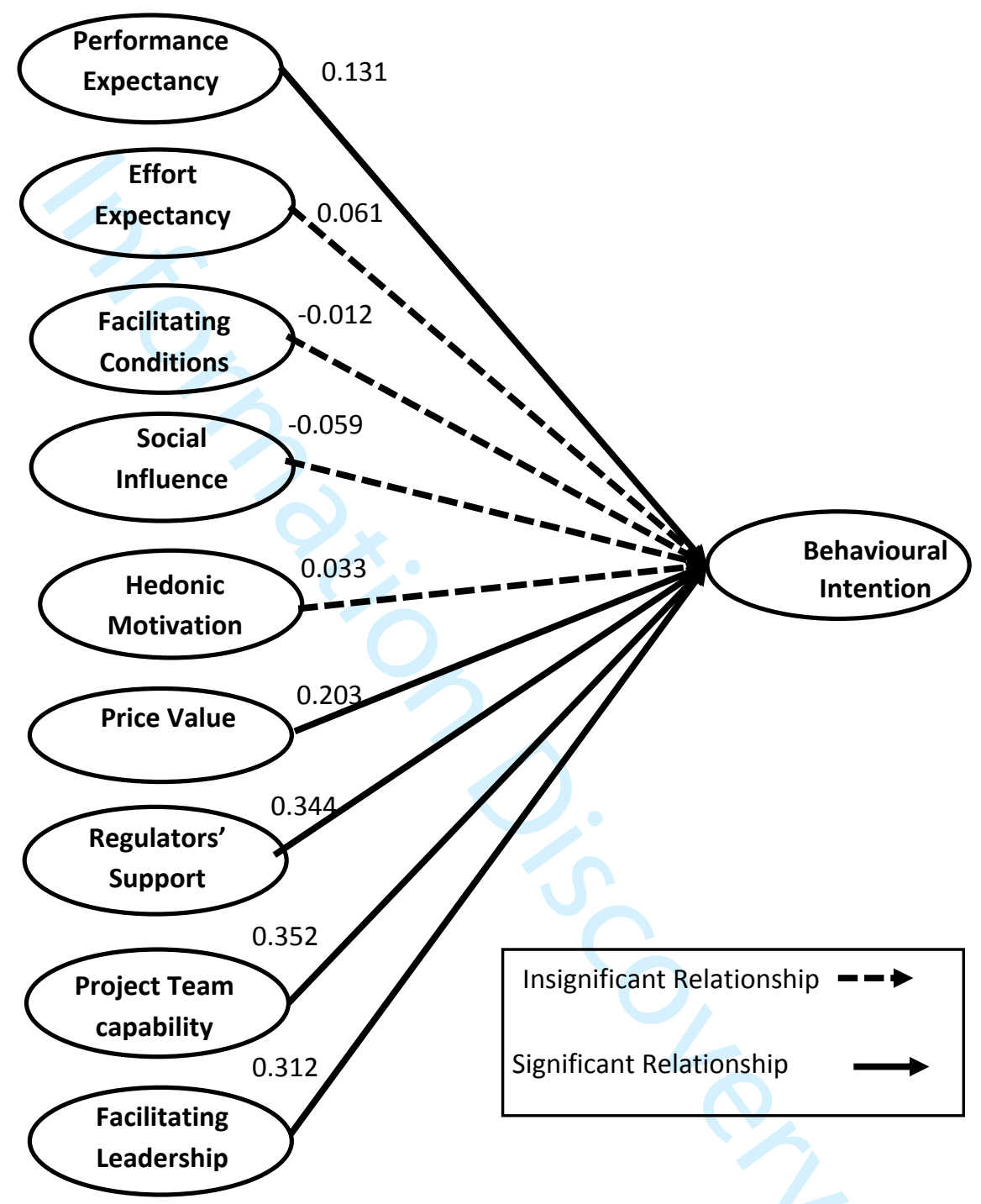

Figure1: Model before conducting online classes 


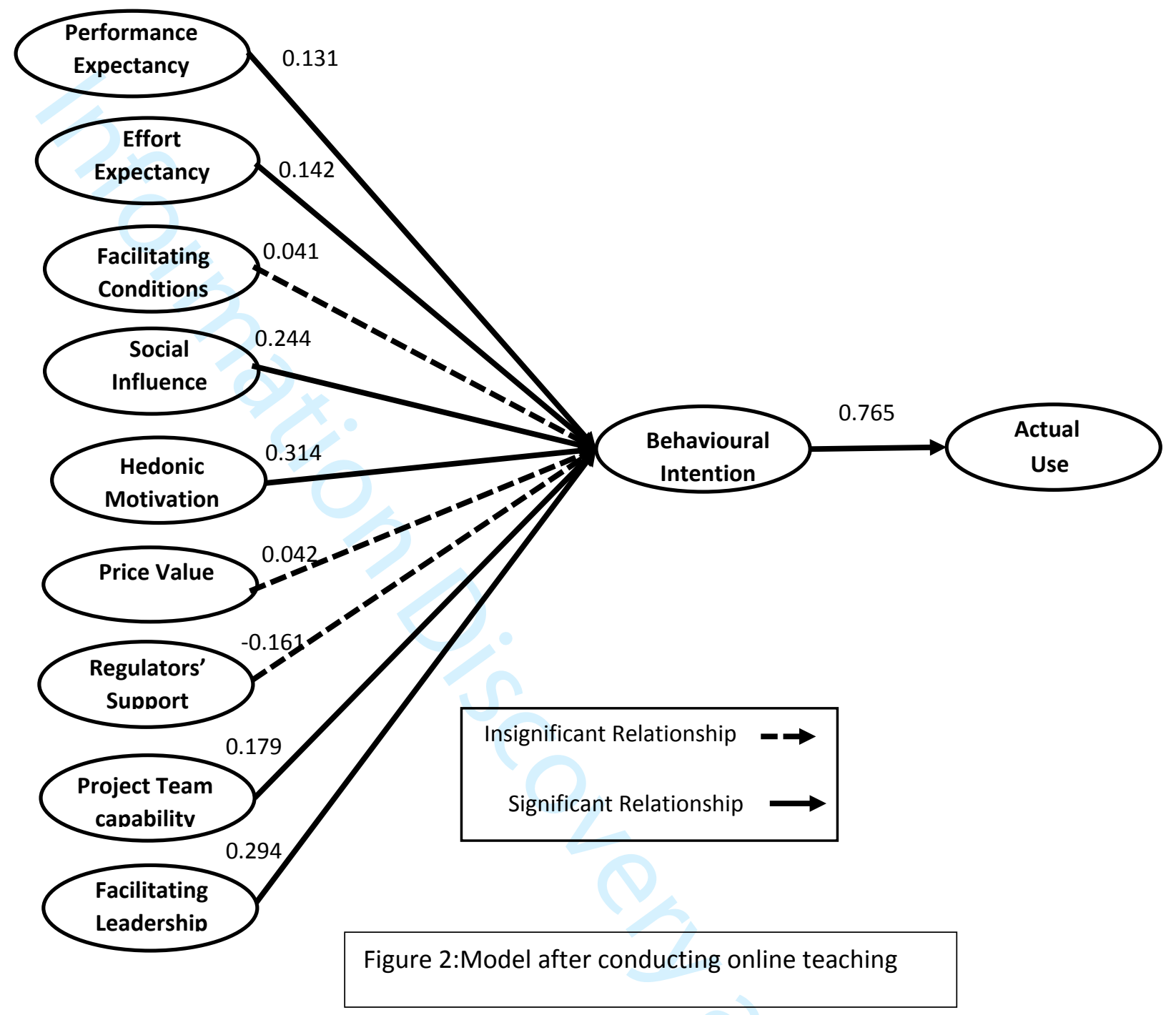

